\title{
English As A Langua Franca: Practices Of Academics in A Turkish University
}

\begin{abstract}
This study aims to identify the problems/difficulties that academics in a Turkish university encounter while using English as a lingua franca. The data were garnered through survey questionnaires filled out by 27 academics based in a Turkish university in the southwest of Turkey. The findings demonstrated that academics dramatically needed and used English in non-native contexts and mainly with non-native speakers of English for various reasons and purposes. Moreover, it was found that participants experienced a large number of misunderstandings and difficulties in the use of English for work-related purposes, and they resented the fact that they had to take English proficiency exams for academic promotion. The results are discussed in relation to those of previous studies of similar scope. The study concludes with suggestions posed for the improvement of academics' verbal and academic writing skills and the issue of language proficiency examination policies.

Keywords: English as a lingua franca, academic English, Turkish academics, the academic world.

\section{Özet}

$\mathrm{Bu}$ çalışma bir Türk üniversitesindeki akademisyenlerin 'anadili farklı insanların konuştuğu ortak dil' (lingua franka) olarak İngilizce'yi kullanma durumlarını ve bu dili kullanırken karşılaştıkları zorlukları belirlemeyi amaçlamaktadır. Araştırmada veriler Türkiye'nin güney batısında yer alan bir Türk üniversitesindeki akademisyenler $(\mathrm{n}=27)$ tarafından doldurulan anketler aracılığıyla toplanmıştır. Sonuçlar katılımcıların çeşitli sebep ve amaçlarla İngilizce'yi anadili İngilizce olan ülkeler dışında ve anadili İngilizce olmayan kişilerle iletişim kurmak amacı ile kullandıklarını göstermiştir. Ayrıca, bulgular katılımcıların İngilizce'yi mesleki amaçlar için kullanırken birçok yanlış anlama ve zorlukla karşılaştıklarını ve terfi edebilmek için yeterlilik sınavlarına zorlanmalarından şikâyet ettiklerini de ortaya koymaktadır. Elde edilen bulgular daha önceki çalışmalar ile karşılıklı olarak tartışılmaktadır ve araştırma akademisyenlerin sözel beceriler ve akademik yazma gibi dil yeterliliklerinin geliştirilmesine ve dil yeterlilik sınav politikası gibi sorunlara yönelik öneriler ile son bulmaktadır.
\end{abstract}

** Araş. Gör. Mehmet Akif Ersoy Üniversitesi, Eğitim Fakültesi 
Anahtar kelimeler: Ana dili farklı olanların konuştuğu ortak dil olarak İngilizce, akademik İngilizce, Türk akademisyenler, akademik çevre.

\section{Introduction}

Nowadays, we frequently hear or read the motto the world is developing into a global village'. Nevertheless, people in this village, do not possess a common language but bring along a variety of languages. Then, the question that how these people communicate with each other arises ipso facto. At this point, English emerges as a global lingua franca by serving as a vital and common means of communication for a large number of people all around the world (Coury, 2001). In a similar vein, Breton (2000) holds the view that "The English language now seems set to have a monopoly as the worldwide medium of communication". As maintained by Crystal (1997) English has hitherto left its marks on each continent and is predominantly spoken over 60 countries either dominantly or officially. This situation leads to increased opportunity and possibility of non-native speakers to meet other speakers of English who are either English or non-English. In such meetings, it is exceedingly likely that "speakers conduct various communicative tasks, from business meetings, academic presentations...to casual chat..." (Cogo, 2009, p. 254). These instances can be multiplied indefinitely. What concerns us is: however,for now, how English has come to hold such an intermediating role in these diverse situations of gathering.

The long-established role of English has shifted from being a foreign language to an international $\backslash$ global language over which any users can assert a right. A variety of factors have contributed to this continuous process of change occurred in the use of English by leading to the spread of English across continents among people of different languages. Of these, the main ones include copious developments having progressively occurred in communication and information technology (e.g. the Internet), advancements and fall of expenses in air transportation, just to name a few. Accordingly, English has eventually come to act like "a bridge of communication" for people from different walks of life who do not share a common language (Gallego, 2012). In this respect, Coury (2001) points to the fact that English may alleviate communication among people engaged in academia, and facilitate access to informationby quoting from Crystal (1997a) that 'Most of the scientific, technological and academic information in the world is expressed in English and over $80 \%$ of all the information stored in electronic retrieval systems is in English' (p.106).The dominance of English in the academic world both in the dissemination and storage of information gives us the right to assert that English has gained the status of 
being a formal and obligatory language of the scientific world with an estimation that " 85 percent of all scientific publications, 75 percent of all international communication in writing, 80 percent of all information in the world's computers, and 90 per cent of Internet content are in English" (Schütz, 2005). In addition, the number of users of English in daily life and on virtual worlds is superior to that of other languages (see Internet World Stats for further detail). Therefore, in the events of contact irrespective of whether on the web or in actual life, it is probable that individuals conduct numerous tasks essentially for utilitarian intentions with the choice of English as the bridge of communication.

Despite the variety of tasks conducted via English and supremacy of English over other languages in academia, there is scarcity of research on the use of English by academics and the challenges they face in their verbal and written ELF communication. Thus, this issue has long remained unexplored vis-à-vis the shifting face of English. This study is motivated to fill this gap by taking the points mentioned above into consideration. To this end, the current study attempts to explore the circumstances in which academics in a Turkish University use English in their work as a Lingua Franca (ELF), and identify misunderstandings and communication breakdowns they already encountered by addressing the following research questions:

1. In which circumstances do academics use English as a Lingua Franca in their work?

2. What kind of problems/misunderstandings do they face while using English as a Lingua Franca?

\section{Literature Review} Lingua Franca

It is of great importance to cast light on the term 'lingua franca' before moving on to discuss the position of English within ELF framework. The term 'lingua franca' is commonly defined as "a language that people use to communicate when they have different first languages" (MacMillan English Dictionary, 2007; p.878; emphasis added). To epitomize the usage of the term in actual use, the following sentence is posed by the dictionary: "German is a useful lingua franca for tourists in the Czech Republic". The exemplar suggests that a lingua franca is in use in non-native contexts i.e. German in the Czech Republic. According to Encyclopaedia Britannica, the origin of the term dates back to Middle Ages when it was initially used "to describe a French- and Italian-based jargon, or pidgin, that was developed by Crusaders and traders in the eastern Mediterranean and characterized by the invariant forms of its nouns, verbs, and adjectives". Since then, many 
languages have undertaken the role of being a lingua franca (once i.e. Greek and Latin). Today's lingua franca is known to be the English language by a wider audience due to the reasons to be elaborated in the subsequent sections.

\section{English as a Lingua Franca}

For roughly three decades (starting from early 1980s), the term "English as a Lingua Franca" has been in the literature of various fields of linguistics. Since then, a great number of definitions have been proposed by scholars according to their own understanding of the term. One of the initial attempts to describe English in relation to the concept of lingua franca was made by Firth (1996) by describing it as "a 'contact language' between persons who share neither a common native tongue nor a common (national) culture and for whom English is the chosen foreign language of communication"(p.240; emphasis in original). Though Firth's definition shows parallelism with MacMillan's above in terms of being a contact language for those having no shared mother tongue and culture, the accentuated word 'foreign' by Firth seems to bar native speakers from ELF interactions given that English cannot be considered foreign to them: however, in that of MacMillan's, the emphasis is on communication among people from different first languages, so, even for the native speaking individuals of English.

The inclusion of native speakers into the ELF communication is also seen in more recent definitions. For example, Jenkins (2009) crudely defines ELF as "English as it is used as a contact language among speakers from different first languages" (p.143). Likewise, the most recent definition made by Seidlhofer (2011) refers to "any use of English among speakers of different first languages for whom English is the communicative medium of choice" (p.7). The up-to-date definitions are the ones which have gained widespread acceptance among researchers working in various areas of linguistics as compared to the Firth's (1996), the boosters of which are in the minority. It is all the more surprising that even dictionaries (e.g. see MacMillan, 2007: p.479) have started to provide definitions for ELF in accordance with the current understanding, which was not the case until recently. This could be taken as evidence that the significance and recognition of ELF is growing over time through continual ELF research in a range of domains such as tourism, business, education and academic settings. In what follows, the focus will be specifically on the use of English in academic contexts by closely scrutinizing the situations in which academics require or are obliged to use English and their past experiences 
regarding their genuine use of the language for several intents and purposes.

\section{English in Academic Settings}

The encroachment of English on the academic world as the leading language is no wonder at all considering the changes the English language and the world have been going through for, at least, three decades. Crystal (1997b), at the very beginning of $21^{\text {st }}$ century, called attention to the point that "... academic worlds demand a world language" (p. 13). It seems so clear that English, as today's lingua franca of communication, is the language to fulfil this demand. This is because it serves as a means of bringing their work to a wider audience in the academic world arena in an attempt to share, disseminate and attain information (Breton, 2000). This weighty role attached to English is well manifested in Graddol's (1997) classification of twelve uppermost domains of English with a ranking of the first two rows as [1]"working language of international organizations and conferences and[2] scientific publications", both of which bear direct relevance to academics in their work environments (quoted in Genc\&Bada, 2010, pp.143-144: Rahimi \& Bagheri, 2011: p. 119).

Academicians are involved in many tasks in their daily professional lives, in which they need to use a shared language of science and research, English today; whereas once it was French and German respectively (see Genc \& Bada, 2010 for further detail). As already stated above, at the very least, they feel pressured to use English in international conferences either as a participant or presenter, in some cases, in both roles. English is also a tool for them to contact their colleagues, follow the research as regards their own fields of study and to communicate with others in plethora of encounters. Above all, they are expected to disseminate their research in English via publications. At that point, academics are not afforded multiple choices but merely two, either to "Publish in English, or perish [?]"(Bakewell, 1992, p.648). The figurative use of the verb "perish" can be best captured as the denial of the promotion and world-wide recognition of the academics on the grounds that they have no publications written in English, as an exemplar case in France reported by Bakewell (1992) also points to this issue. And this results in either stoppage or delay of academic advancement of the faculty members as they move up the path of academic career.

In light of the above argument, Bakopoulos (1997) draws our attention to a very crucial reality, by citing a graduate student in a panel, the theme of which is whether English is a threat to academic cultures, that "many great minds" might go unnoticed and remain nameless in the 
academic arena due to not publishing research in English. The current situation seems to militate against those who publish in other languages but English. This is because the findings of a study conducted by NarvaezBerthelemot and Russell (2001) showcased that English is the predominant language of publishing for voluminous journals regardless of where these journals are based (cited in Rahimi \& Bagheri, 2011).

Another development that has already reignited the above discussion even more is the fact that English in academia is mostly used by non-native speakers of English, as this is the case for general English (Maurenan, 2008). Regarding this, many practices in academic contexts such as lectures, seminars, thesis defences, and conference presentations, to name a few, have come to the fore since there has been a shift towards conducting these practices via English. As a result, English as a Lingua Franca in Academic settings, abbreviated as ELFA, emerged as research domain and been subject to a great amount of research. Still more, a corpus has been compiled by a research team under the leadership of Anna Mauranen in Finnland (Maurenan, 2003; for further details about the corpus visit www.helsinki.fi/englanti/elfa/) to investigate the use of English in academic settings. One more attempt, reported by Maurenan (2008), is SELF (Study of English as a Lingua Franca) which in the main aims to examine people's experiences in academic ELF communications and their academic practices, exclusively in non-English English speaking settings.

In relation to the aforementioned contentions, several studies have been carried out to probe the practices of academics with reference to the use of English in their professional contexts and the language related obstacles they encountered in lingua franca communications. For example, the research undertaken in Brazil (Coury, 2001) aimed to explore situations in which 20 Brazilian academics working at different universities use English as ELF and the potential misapprehensions and complications they might face in their ELF use. The data collected through questionnaires and interviews indicated that there exist myriad contexts of use in which the academics were actively involved, which are presented in the subsequent lines: as a means of communication with others (i.e. colleagues, editors) over the world via various tools of communication, writing papers for conferences and publishing houses, talking to attendees at the conferences, doing research both on hard copy materials and the Internet, speaking to guests visiting the institutions, just to name the frequently pointed ones.

As to the misunderstandings and difficulties they experienced in writing, the participants reported that they had trouble writing emails/letters, papers for conferences, problems with register, all stemming 
from false cognates and misuse of loan words. They remarked that the referees found some terms hard to understand since the L1 resources influenced their writing, namely, they deviated from the expected standards. With regards to face-to-face obstacles, they brought up issues concerning breakdowns in communication due to differences in the pronunciation of individual sounds resulted from L1 characteristics, unawareness of crosscultural pragmatic skills, and incorporation of false cognates into their speeches in the wrong ways, and mispronunciations.

\section{Background to the study}

Turkish academics cannot remain unconcerned about the allimportant role of English, which plays a major part for their current and future career in their attempt of climbing up the promotion ladders at work. For them, English is neither a mother tongue nor a second language, yet a language that they need for instrumental inducements such as gaining access to a wider audience, following the researchers in their fields and conducting research, to mention but a few. However, they are coerced to diffuse the findings of their research in another language, English, rather than their own first language by their institutions' and publishing houses. Even if when they write in Turkish for a national journal or science magazine, it is by and large compulsory for them, at least, to provide an abstract written in formal and Standard English. Worse than this, many academics end up their career without taking the fruit of their long-term investment and effort in their vocation owing to either failure to pass English exams or having no publications written in the English language. Even if they strive to publish in English, they are challenged by editors since they do not, more accurately, are not able to adjust to so-called standard and native-like proficiency in writing. Therefore, it has become a "matter of life and death" for the researchers to battle with English so as to remain alive in their professional life.

\section{Methods}

\section{Research Design}

This study was designed as a descriptive and qualitative study which intends to investigate the practices of academics from different ranks in using English for academic and individual purposes by particularly looking at the difficulties they perceived while using English either in written or oral communication. 


\section{Participants}

27 academics all, at present, working in a Turkish university in Burdur, located in the southwest of Turkey, took part in the study of their own accord. The selection of the participants was based on purposive sampling in which "each element [participant] is selected for a purpose, usually because of the unique position of the sample elements" (Engel \& Schutt, 2009, p. 96) and in our case, the distinctive position of the participants are derived from their being academics in the university, which is the target setting of the current study. Of the participants, 16 were males $(59 \%)$ and 10 were females (37\%). One of the participants (4\%) failed to mark the gender choice in the questionnaire. In regards to the faculties and departments where they serve their time, the respondents come from three different faculties namely: school of education, school of arts and sciences, and school of veterinary science, more precisely from diverse departments of these three faculties. As to their academic titles, academic staff members of all titles excluding 'the title' Prof. Dr. are represented in the study. However, some respondents did not specify their academic title. The demographic information pertaining to the participants' gender, departments or duty station and the titles they hold are given in Table 1.

Table 1: Demographic information about the respondents of the study $(\mathrm{n}=27)$.

\begin{tabular}{|c|c|c|c|c|c|c|c|c|}
\hline Gender & $f$ & $\%$ & Faculties & $f$ & $\%$ & Titles & $f$ & $\%$ \\
\hline Male & 16 & 59 & Education & 16 & 59 & $\begin{array}{l}\text { Assoc. Dr. } \\
\text { Asst. Prof. Dr. }\end{array}$ & $\begin{array}{l}1 \\
12\end{array}$ & $\begin{array}{l}4 \\
44\end{array}$ \\
\hline Female & 10 & 37 & Veterinary & 8 & 30 & $\begin{array}{l}\text { Lecturer } \\
\text { Res. Asst. }\end{array}$ & $\begin{array}{l}2 \\
9\end{array}$ & $\begin{array}{l}8 \\
32\end{array}$ \\
\hline Missing & 1 & 4 & $\begin{array}{l}\text { Arts and } \\
\text { Sciences }\end{array}$ & 3 & 11 & $\begin{array}{l}\text { Specialist } \\
\text { Missing }\end{array}$ & $\begin{array}{l}2 \\
1\end{array}$ & $\begin{array}{l}8 \\
4\end{array}$ \\
\hline Total & 27 & 100 & Total & 27 & 100 & Total & 27 & 100 \\
\hline
\end{tabular}

\section{Data Collection Tool}

The data were collected through a questionnaire adjusted from Coury (2001). It was composed of a total of thirteen questions, three of which are open-ended and optional to answer. The first three questions were related to the demographic background of the participants. The rest of the questions were asked to learn about whether the respondents have been abroad, which languages they have used for communication, for what purposes they needed English, whether they took an international or national language exam, and if they did so for what purposes, and lastly the 
problems and misunderstandings they faced while using English as a lingua franca.

\section{Data Analysis}

The data were analysed both quantitatively and qualitatively. For quantitative analysis, SPSS 16 statistical programmer was utilized to describe the data in percentages and frequencies. On the other hand, for qualitative data, Nvivo, qualitative data analysis software, was used to organize and interpret the data, particularly the unstructured data. The outcomes of the quantitative analyses were tabulated.

\section{Results and Discussion}

In this part of the paper, the results obtained from the analyses will be presented in tables with following discussions for each of the item of the questionnaire under analysis.

Table 2: The number of academics gone abroad and the language they used.

\begin{tabular}{lll|lll}
\hline $\begin{array}{l}\text { Have you ever been } \\
\text { abroad? }\end{array}$ & $\mathrm{f}$ & \multicolumn{2}{c}{$\begin{array}{l}\text { The language used } \\
\text { abroad }\end{array}$} & $\mathrm{f}$ & $\%$ \\
\hline Yes & 20 & 74 & English & 18 & 90 \\
No & 7 & 26 & German & 1 & 5 \\
& & & English-German & 1 & 5 \\
\hline
\end{tabular}

As can be seen from Table 2, the majority of the participants (74\%) have been abroad while the rest $(26 \%)$ have not. Those who have gone abroad were mainly composed of academic staff of higher rank. On the other hand, those who have spent their time in homeland were mostly research assistants, who were more inexperienced and less mobile than the academics of higher rank. A great number of respondents $(90 \%)$ declared that they used English as the single means of communication with others while abroad whereas only one used German and another participant used both English and German. This demonstrates that English is by far the most common language used for communicative activities by Turkish academics. What is notable is that except few academics, most of them have been to outer and expanding circle countries (see Kachru, 1992) where English is not used or spoken as the mother tongue. For this reason, they were inevitably involved in interaction more with non-native speakers of English than they did with native speakers of English, which is congruent with Maurenan's (2008) assertion that English in academic circles is predominantly utilized by non-native academicians and it is "unquestionably the world language of academia" (Maurenan, Hynninen \& Ranta, 2010, p. 183) by superseding 
other so-called modern languages such as German and French in academic contexts.

As to the question that probes for what purposes and in which circumstances English is used, the respondents, as can be concisely seen in Table 3, appeared to use English for a variety of reasons and in several work-related conditions. Three participants did not specify any purposes regarding the use of English. The responses received, therefore, remained limited with 24 respondents.

It is clearly seen that academics chiefly use English for research purposes; that is to say, their top priority is centred on their professional sustainability through constant research. For them, English is as a means to take advantage of on the road to their professional growth and development. As clearly seen, all the responses given by the participants are instrumentally driven. In other words, academics need and use English for basically work-related instrumental reasons rather than integrate with the members of a particular language community. The details of the responses received from 24 participants are displayed in Table 3:

Table 3: The purposes and situations in which academics use English at work

\begin{tabular}{lll}
\hline The reasons for using English at work & f & \% \\
\hline to do research on the Internet & 22 & 88 \\
to do research from the books written in English & 22 & 88 \\
to translate papers from English into Turkish & 20 & 80 \\
to communicate with the people around the world by e-mail & 16 & 64 \\
to write papers for conferences & 16 & 64 \\
to talk to people at international conferences & 13 & 52 \\
to translate papers from Turkish into English & 10 & 40 \\
to talk to English speaking visitors who visit their institution & 9 & 36 \\
to communicate with the people around the world by telephone & 4 & 16 \\
to communicate with the people around the world by fax & 1 & 4 \\
to communicate with the people around the world by letter & 1 & 4 \\
to talk to people at national conferences & 1 & 4 \\
Other & 1 & 4 \\
\hline
\end{tabular}

Communication via different tools and research on the Internet and from articles and books circulated in English are the main objectives of the academics in the use of English as a lingua franca. Their lingua franca communication is more frequently exchanged by electronic mails than other means of communication, for instance, fax, letters and telephone calls, since e-mailing is faster and more comfortable for them. 
The large number of participants using English for conducting online and library research, and writing papers for conferences points to a policy set by the university and the CHE (the council of higher education) that puts pressure on them to produce and publish academic papers in English, attend conferences and present their papers. If they fail to do so, they will face the risk of being deprived of many benefits of the institution and their own works such as getting funding, being promoted, and having nationwide or worldwide recognition in his/her field of research. On the other hand, it is an indication of the fact that a large and mounting number of these activities particularly those based on texts, for example, research papers, dissertations and theses, lectures are carried out by non-native speaker academics and researchers (Römer \& Arbor, 2009).

Another case in point is the issue of translation. The academics and researchers, whose major is not English, find it hard to write and publish articles, and give a conference talk in English. As a solution to this challenge, they prefer to write in Turkish first as a common practice, and then make their papers translated for various purposes ranging from presentations to seminars.

Following the purposes of English use, the respondents, later on, were asked to name the language tests they took in English. It was found that they took both national and international English language examinations for different purposes, all of which are based on work-related whys and wherefores. The exams partnered with the reasons of taking them are summarized in the following Table 4 and 5 as reported by the participants.

Table 4: The exams taken by the participants

\begin{tabular}{llll}
\hline \multicolumn{2}{l}{ The exams taken by the academics } & f & $\mathbf{\%}$ \\
\hline KPDS & (Kamu Personeli Dil sinavi) & 20 & 83 \\
UDS & (Universitelerarası Dil Sinavi) & 24 & 100 \\
IELTS & (International English Language Testing System) & 1 & 4 \\
TOEFL (Test Of English as a Foreign Language) & 2 & 8 \\
\hline
\end{tabular}

As can be seen in Table 4, a great number of academics took national language exams (i.e. KPDS and UDS). The reason is that academics need to pass these exams by getting a valid test-score to request either a promotion or a higher title.

Only three participants took international language exams (i.e. IELTS and TOEFL). Probably, it is more difficult to get preset scores from these exams. This is because their assessment of language proficiency is dependent on four main language skills, namely: listening, speaking, writing and reading whereas listening and speaking are not available in the national 
exams. Not only academics but also students who want to pursue MA and $\mathrm{Ph} . \mathrm{D}$ are subjected to these exams for admission. Those who fail to get enough scores already lose the opportunity to be a researcher or an academic. Such a practice brings us to the point raised by Bakewell (1992) that they either have to receive a valid test-score or suffer in their academic life even before taking the first step to a master program.

As for the the reasons for taking such exams, the participants reported several motives that are all professinally driven. The most frequent motive $(83 \%)$ stands out as promotion which can be taken as a change of title to a higher rank such as promotion from assistant to assocciate professor, promotion from associate to full professor. Following promotion, the rest of the motives can be enumerated in order of frequency as post-graduate studies, improving the language, receiving a grant and pleasure, acceptance to an international university abroad and other driving forces, which are all illustrated in Table 5.

Table 5: The motives for taking English language exams

\begin{tabular}{lll}
\hline The reasons for taking English language exams & $\mathbf{f}$ & $\mathbf{\%}$ \\
\hline to be promoted & 18 & 82 \\
to continue with my post-graduate studies & 9 & 41 \\
to improve in the language & 5 & 23 \\
Other & 4 & 18 \\
to receive grant from a Turkish (government or YOK) sponsor & 2 & 9 \\
for pleasure & 2 & 9 \\
to be accepted in a university abroad & 1 & 5 \\
\hline
\end{tabular}

It is as clear as daylight from Table 5 that academics take the English language exams, being instrumentally motivated since taking such exams is practiced solely for "utilitarian motives"(Baker, 1988, p.153: Baker, 1992, p.32) like getting a grant rather than appreciating the language and building personal rapport with the community who speak it. In a similar vein, Alptekin's (2002)argument from the lingua franca perspective that "much of the world needs and uses English for instrumental reasons such as professional contacts, academic studies and commercial pursuits" (2002, p.61; emphasis added)truly corroborates the above findings.

Once the respondents were asked whether they resented taking these exams to achieve preordained test scores, $44 \%$ of them $(n=12)$ responded to the question with YES while $48 \%(n=13)$ said NO and $8 \%(n=2)$ failed to provide any answer to the question. These results are clear indication of the fact that they are forced to take these exams instead of taking them voluntarily. The subsequent question was directed at those who 
said YES to discover the reasons why they felt resentment. According to results of the analysis, three categories emerged and they are outlined as follows in order of frequency: a sense of failure in the exam, lack of intrinsic motivation, and difference between the language in exam and in daily life. The majority of participants felt anxious since their promotion rests on the results of the exams, some are against its being mandatory in that it reduces their enthusiasm for learning English. The conclusion to be drawn from their expressions is that forcing the academics to take obligatory tests for promotion leads to lack of motivation on learning English and does not help them gain proficiency to succeed at using English for academic and communicative purposes. This case can be roughly explained as using and appreciating English until receiving an admissible test-score from one of the examinations.

The participants also reported that they use English words and terms relating to their area of work by incorporating them into Turkish while lecturing and exchanging talk with their colleagues and students. The principal words they use are composed of a group of words included in a list in the succeeding lines as written by the academics: reflection, insert, download, translate, relaks [relax], senkron [synchronous], yes, ok, performance, good, play, nice, research, comication [communication], curriculum, purpose, aim, verification, management, delete, mouse, data, conceptus, effective [effective], background, Voltage, Current, Oscillator. This, as well, points out that their choice of loan words is limited to the terms and words generally related to their own fields of activity and research as well as words used in ordinary English.

The last two questions dealt with the misunderstandings academics experienced whilst speaking with other speakers of English. They were also requested to write about their experiences of misunderstandings and difficulties during the use of English. Out of 25 participants having responded to the question, $13(48 \%)$ said that they suffered from a series of notable misunderstandings that exacerbated their communication. 12 (44\%) participants stated that they have not been in conflict situations that would create misunderstandings as they use English. According to the analysis of the given answers, the misunderstandings in the main stemmed from mispronunciation of words, lack of vocabulary knowledge, lack of fluency, which all resulted in loss of intelligibility in their perception of the ELF communication. At bottom, all these sources of misunderstandings arise from pronunciation errors including misintonations and faulty-stress in participants' own words, which are, as a result of being obsessed with native speakerism, all measured against the standards of native English speakers. 
Participants, in the main, perceived misunderstandings as though they were only pertinent to the verbal communication. None of the participants mentioned misunderstandings that they have had in written English. This comes as a surprise considering the responses they gave in Table 3. They expressed that they wrote papers in English for conferences and scientific publications in different journals and magazines together with proceeding books. However, participants in Coury's (2001) study reported that the common problems they faced in writing consisted of faulty cognates, loan words, register-based issues and many papers were rejected due to these matters. This can be possibly explained with the general practice of the majority of Turkish academics, who first write in Turkish and next make their papers translated in an attempt to produce papers close in quality to those of native speakers. Since they are not involved in the writing process without help from others, they do not sense too much challenge or difficulty in respect of writing in English when compared to those who struggle to write with their own efforts and means as practised among the participants of Coury's research.

\section{Conclusion and Recommendations}

The main objective of this study was to explore the situations where the academics used and needed English in their workplace. In particular, it sought to find out what kind of problems and misunderstandings they had to cope with while using English for work-related purposes. Reviewing the previous studies and current research, it is obvious that English is being predominantly and extensively used among non-native academics of English in lingua franca circumstances for a range of purposes. As the findings of this study reveal, Turkish academics, with a thumping majority and for a wide variety of practical reasons, use and need the English language in the workplace (see Table 3).

It is also demonstrated that they are confronted with sundry problems and misunderstandings when using English, the majority of which are alleged to derive from pronunciation errors, which is parallel to the findings of earlier studies. However, when the point in question is written English, they seem to have no perception of challenge or misunderstanding, which was not reported in previous studies, owing to the fact that their papers written in the mother tongue are translated into English either by translators or their colleagues/assistants who are good at written English. This is strong evidence that the examinations force them to conform to the written standards of native-speakers. As they know that they will fail to fulfil these criteria, they turn to the practice of translation. 
It might be inferred that the imposition of English or another language on academics as a criterion for promotion seems to exert a negative influence and coercive pressure on them, driving them to develop practically and goal-oriented attitudes towards English. This has, in effect, adverse impacts on their communicative use of the language in lingua franca situations because they primarily focus their attention on passive skills such as reading with a view to obtain an acceptable test-score to apply for promotion. Therefore, there is an urgent need to amend the policies of the institution and the CHE, by quitting imposing English as a barrier to overcome through examinations. As an alternative, they had better start to incite English as global academic lingua franca without impeding their professional development with impractical examinations, which are already open to question in terms of quality and reliability and their constructive wash-back effects on examinees.

The only pseudo-benefit of the aforesaid policy is to help academics develop tips and tactics for examinations and use a few English words in their L1 use. The same policy is also adopted by both some national and many international journals published in English, whose referees are primarily composed of native speakers of English. For that reason, Turkish academics have difficulty publishing and disseminating research in highly prestigious journals and magazines, which urges them to conform to NS norms in writing research papers in English, even if their works do not address native speakers of English.

To recap for concluding the paper, the new role of English as a lingua franca appears to be operative in the academic environments due the increased number of non-native academics. The use of English whether for written or communicational intentions is essentially based on practical vocational activities including chiefly research, and exchanging information or ideas concerning their fields of study with their colleagues from different countries particularly from outer and expanding circle locations through various communication tools or in person. Some policies like the implementation of language proficiency exams as a requirement for promotion leads to academics' spending a great amount of time on preparation for exams all for nothing, which could otherwise be spared to conducting research activities on their own field. In addition, more than half of the academics feel resentment for having to take exams that will influence their academic and career progression. The academics live through many misunderstandings especially in oral ELF interaction thanks to the perceived pronunciation errors which reduce comprehensibility according to their perception. Considering all these issues discussed above, this paper will 
conclude with the following suggestions on the use of English as an academic lingua franca among Turkish academics under the light of the findings of the present and former studies:

The policy that entails academics to take either national or international English proficiency tests in order that they can apply for a promotion should be changed since it does not serve the rationale of putting these exams into practice, which basically aims to equip academics with language skills in order to pursue their scientific and academic studies. The intention is worth appreciating; however, the practice is questionable. Therefore, I hereby suggest offering in-service language support services with vocational courses, and the participation should be on a voluntary basis. The promotion criterion should not alone be grounded on the language exam but include academics' performances, skills and abilities in their own field. In short, a portfolio approach should be embraced while deciding on a promotion of the academics.

They should be encouraged to read and write research papers instead of falling back on the translation by others. Through first-hand experience, their understanding and writing, particularly their field knowledge will increase more in quality and quantity.

Their speaking skills are as important as their writing skills in academia considering the situations they reported using English like conferences, lectures and seminars where they need English as the tool for communication. Therefore, they need assistance in improving their oral skills especially for ELF interactions. For this purpose, speaking clubs can be useful under the guidance of academics whose majors are English. Through such a practice, the aim should be to improve academics' communicative effectiveness rather than traditionally targeting at 'bookish English' based on native speakers which are marketed as the correct and standard to the customers i.e. academics in this case.

Finally, the institution might establish a unit to provide academic guidance for academics in matters involving proofreading, guidance, register, corrections demanded by the editors, to name a few. Such units already exist in many universities in Europe. The same implementation might be adopted in Turkish universities, as well. At this juncture, it is again worth mentioning that the goal is not to drive academics to the so-perceived native speaker written forms but to make their work widely apprehensible to a broader audience, the majority of who are non-native English. 


\section{References}

Alptekin, C. (2002). Towards Intercultural Communicative Competence. ELT Journal, 56 (1).

Baker, C. (1988). Key issues in bilingualism and bilingual education. Clevedon: Multilingual Matters Ltd.

Baker, C. (1992). Attitudes and Language. Clevedon: Multilingual Matters Ltd.

Bakewell, D. (1992). Publish in English, or perish? Nature, 356(23 April), 648. Retrieved February 29, 2012, from http://proquest.umi.com/pqdweb?index $=12 \&$ did $=1729840 \& S$ rchMode $=3 \&$ si $=2 \&$ Fmt $=6 \&$ VInst $=$ PROD $\&$ VType $=$ PQD

Bakopoulos, D. (1997, January 28). English as universal academic language: Good or bad? The University Record. Retrieved February 15, 2012, from http://www.umich.edu/ urecord/9697/Jan28_97/artcl18.htm

Breton, R. J.-L. (2000). Can English be dethroned? The Courier. Retrieved February 12, 2012, from http://www.unesco.org/courier/2000 04/uk/doss11.htm

Cogo, A. (2009) Accommodating difference in ELF conversations: a study of pragmatic strategies. In Mauranen, Anna; Ranta, Elina (eds.). English as a Lingua Franca: Studies and findings. Cambridge Scholars Press, 254-273.

Coury, J. G. (2001). English as Lingua Franca in the Brazilian Academic World.Retrieved February 10, 2012 from http://www3.telus.net/linguisticsissues/linguafranca.htm.

Crystal, D (1997a). The Cambridge Encyclopaedia of the English Language, Cambridge: Cambridge University Press.

Crystal, D. (1997b). The language that took over the world. Retrieved February 15, 2012, from http://www.davidcrystal.com/DC articles/English39.pdf

Firth, A. (1996). The discursive accomplishment of normality: On "lingua franca" English and conversation analysis. Journal of Pragmatics, 26(2), 237-259.

Engel, R., \& Schutt, R. K. (2009). The Practice of Research in Social Work. Thousand Oaks, CA: Sage.

Gallego, F. M. D. (2012). Experiences of a teacher of English. Retrieved February 5, 2012, from http://fernandoexperiences.blogspot.com/2012/02/792-english-as-bridge-ofcommunication.html

Graddol, D. (1997). The future of English. London: The British Council. 
Genç, B. (2010).English as a World Language in Academic Writing.Reading Matrix, 10(2), 142-151.tt

Jenkins, J. (2009). World Englishes: a resource book for students. English. Routledge.

Kachru, B. B. (1992). The other tongue: English across cultures (2nd. edition). Urbana IL.: University of Illinois Press.

MacMillan Dictionary for Advanced Learners (2007). MacMillan Publishers Ltd.

Mauranen, A. (2003). The corpus of English as a lingua franca in academic settings. TESOL Quarterly, 37(3), 513-527.

Mauranen, A., \&Ranta, E. (2008).English as an Academic Lingua Franca - the ELFA project. Regulation, 7(3), 199-202.

Mauranen, A., Hynninen, N. \& Ranta, E. (2010). English as an Academic Lingua Franca:The ELFA Project. English for Specific Purposes, 29, 183-190.

Narvaez-Berthelemot, N., \& Russell, J. (2001). World distribution of social science journals: A view from the periphery. Scientometrics, 51(1), 223-239.

Rahimi, F., \& Bagheri, M. S. (2011). On the Status of English as a “ Lingua Franca ": An EFL Academic Context Survey, 3(2), 118-122.

Römer, U. \&Arbor, A.( 2009). English in academia: Does nativeness matter? Anglistik: International Journal of English Studies 20(2), (89-100).

Schütz, R. (2005). English-The international language. Retrieved February 20, 2012, from http://www.sk.com.br/sk-ingl.html

Seidlhofer, B. (2011). Understanding English as a Lingua Franca. Oxford: Oxford University Press.

http://www.helsinki.fi/varieng/CoRD/corpora/ELFA/index.html 


\section{Appendix}

Dear Sir or Madam,

Currently, I am doing some research in the area of English as a lingua franca in the Turkish Academic World. I would be deeply grateful to you, if you could answer the following questions. The answers to the questionnaire will be kept confidential and be used only in accordance with research objectives. Thank you for your participation and cooperation.

1. Gender: ๑ male ๑f female

2. In which department do you work?

3. Your title:

๑ Research Assistant ๑ Lecturer ๑ Asst. Prof. Dr. ๑ Assoc. Prof. Dr. ๑ Prof. Dr.

4. Have you ever been abroad? (If yes, please write the name of the country/countries)
(1) yes
(2) no

5. Which language(s) do you speak to communicate with others when you go abroad?

๑) English @ German (๑) French ๑ Other-s- ( )

6. At work, in which of the following circumstances do you use English? Please tick the relevant boxes).

(1) to communicate with people around the world by e-mail

(2) to communicate with people around the world by fax

(-) to communicate with people around the world by telephone

๑) to communicate with people around the world by letter

(-) to do research on the internet

(-) to do research from books written in English

(-) to write papers for conferences

ه to talk to English speaking visitors who visit your university

(-) to talk to people at national conferences

๑ to talk to people at international conferences

(-) to translate papers from Turkish into English

(-) to translate papers from English into Turkish

(-) other (please specify) 
7. Have you ever taken any of the following English tests? Please tick the relevant box(es).

(1) IELTS TOEFL ๑ UDS ๑ KPDS ๑ other ( )

8. If you have done an English test, why did you take it? Please tick the relevant box(es).

(อ) to receive a grant from a Turkish (Government or YOK) sponsor

(-) to be accepted in a university abroad

(-) to continue with my post-graduate studies

(-) to improve in the language

(-) for pleasure

(2) to be promoted

(-) other (please specify)

9. If you were obliged to take an English test, did you resent the fact that you needed a certain grade in order to do what you wanted to achieve? Please tick the relevant box.
(-) yes
(1) no

10. If you answered yes to the previous question, why did you resent the fact?

11. Do you use any English words/terms in your area of work which you have incorporated into your Turkish vocabulary? For example, marketing, delete, etc. If so which ones? Please state below.

12. Have you ever had any misunderstandings with other English speakers because of the English language? Please, tick the relevant box.

(-) yes 0 no

13. If you would like to, please state below which misunderstandings you have had. 